V.V. Hnatushenko ${ }^{1}$, Dr. Sc. (Tech.), Prof., orcid.org/0000-0003-3140-3788, D. K. Mozgovoy ${ }^{2}$, Cand. Sc. (Tech.), orcid.org/0000-0003-1632-1565,

V.V. Hnatushenko ${ }^{1}$, Dr. Sc. (Tech.), Assoc. Prof., orcid.org/0000-0001-5304-4144, V. V.Spirintsev1, Cand. Sc. (Tech), Assoc. Prof., orcid.org/0000-0002-0908-1180,

I. M. Udovyk ${ }^{1}$, Cand. Sc. (Tech.), Assoc. Prof., orcid.org/0000-0002-5190-841X

\title{
ALL-WEATHER MONITORING OF OIL AND GAS PRODUCTION AREAS USING SATELLITE DATA
}

Purpose. Development and testing of an information technology for automated processing of medium-resolution satellite images acquired at different times for all-weather monitoring of oil and gas production areas.

Methodology. The information technology implies the use of two algorithms. The algorithm for automated recognition of new oil extraction sites is based on computing the normalized difference index (NDI) of temporal changes for a given pair of satellite images in visible and near-IR bands acquired at different times and selected spectral cannels with subsequent multi-threshold binarization. The algorithm for automated recognition of large metal objects uses bipolarized C-band radar images from Sentinel-1A/B satellites.

Findings. The proposed information technology made it possible to automatically detect the new oil extraction sites and recognition of large metal objects. The overall recognition accuracy, averaged for 20 test areas, was from 87 to $91 \%$ with the kappa coefficient ranging from 0.82 to 0.85 . For cloud-covered areas the big metal objects (an extraction units, automotive equipment for oil transportation, etc.) were recognized using SAR imagery from Sentinel-1A/B satellites only.

Originality. Unlike the existing methods for detection of anthropogenic changes of the Earth's surface by satellite images, the proposed information technology uses immediate calculation of the normalized difference index of temporal changes NDI for a given pair of satellite images acquired at different times, which considerably reduces requirements to the computing power while ensuring higher accuracy of the allocation of the boundaries of new oil production sites. All-weather monitoring is provided using radar data.

Practical value. Owing to high degree of automation, the developed technology can be implemented as a geoinformation web service for all-weather up-to-the-date monitoring of oil extraction areas. This web service can be used to determine the area of fields, control production activity and estimate oil production, supervise development and production activities and assess anthropogenic load in oil production areas.

Keywords: oil extraction monitoring, Sentinel-1A/B, Sentinel-2A/B, multispectral images, image processing, detection of changes

Introduction. Currently, oil and gas are the most important types of natural resources without which no developed country can exist. The volume of oil production is directly related to the level of economic development of some countries. Therefore, the task of assessment of the production activity of existing oil and gas fields, as well as monitoring of the construction of new oil and gas production sites, is very important [1,2]. The development of new methods for oil-and-gas infrastructure objects and the environmental state into the practice of the oil and gas industry is of exceptional importance [3].

Statement of the research problem. In recent years, Earth remote sensing data are increasingly being used to determine the extent, dynamics and consequences of the anthropogenic environment destruction [4], including that as a result of oil and gas production $[5,6]$. Satellite monitoring, compared to terrestrial measurement methods, has numerous undeniable advantages [7, 8]. Since the commissioning of the second Sentinel-2B satellite in 2017, the Copernicus system has become the most informative and affordable source of remote sensing data of medium spatial resolution. This can be judged by the large number of web services providing a wide range of information products, mainly based on optical images from Sentinel-2A and Sentinel-2B satellites. This can be explained by a successful combination of high-quality characteristics of the images themselves (rather high spatial and radiometric resolution, a variety of spectral channels) and frequent revisiting of same places (5 days for two satellites).

Purpose. Unfortunately, the most common and informative multispectral satellite imagery in the visible and infrared

(C) Hnatushenko V.V., Mozgovoy D. K., Hnatushenko V.V., Spirintsev V. V., Udovyk I. M., 2019 ranges has two significant limitations as a source of the survey:

- the need for adequate illumination of the surveyed territory (as a rule, high-quality imaging is possible at the Sun elevation angles of more than $30^{\circ}$ );

- strong dependence on the presence of clouds over the surveyed territory (the maximum permissible percentage of cloud cover is usually not more than 2 to $5 \%$ ).

Therefore, the actual frequency of imaging in optical channels for Sentinel 2A/B satellites, even for small areas, is much lower (sometimes by several times). The use of data from other medium resolution remote sensing satellites, Landsat-7, Landsat-8 [9] and Terra (ASTER multispectral radiometer), as additional free sources is not always possible due to the poorer characteristics of these images, and also due to the presence of clouds.

Possible ways to solve the problem. Therefore, to ensure allweather satellite monitoring of the dynamics and consequences of anthropogenic changes in areas of oil and gas production sites, in addition to satellite imagery in the visible and infrared bands, it is necessary to use bipolarization radar imaging data in the C-band obtained from medium-resolution remote sensing satellites equipped with synthesized aperture radar. In this case, it is possible to partially improve the frequency of obtaining information from the desired territory by radar imaging, one of the main advantages of which is not being dependent on clouds [10].

Fig. 1 shows comparison of the dual-polarization C-band radar image from the Sentinel 1A satellite (left) and optical multispectral visible band image from the Sentinel 2A satellite (right) for the same territory and day of survey.

The main objective of this research is to develop and test the technology for automated processing of medium spatial resolution optical and radar data from the Sentinel 1A/B [10] and 


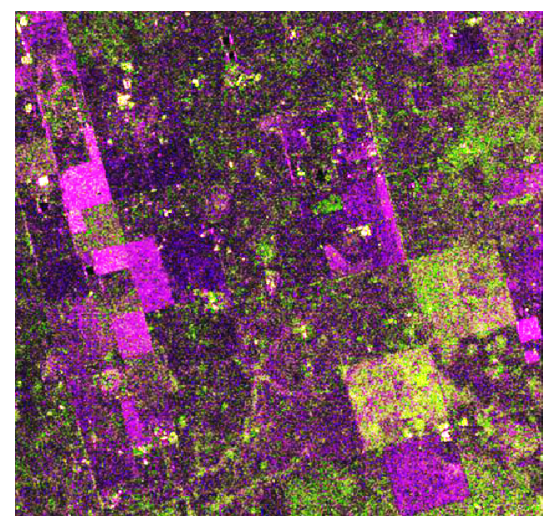

$a$

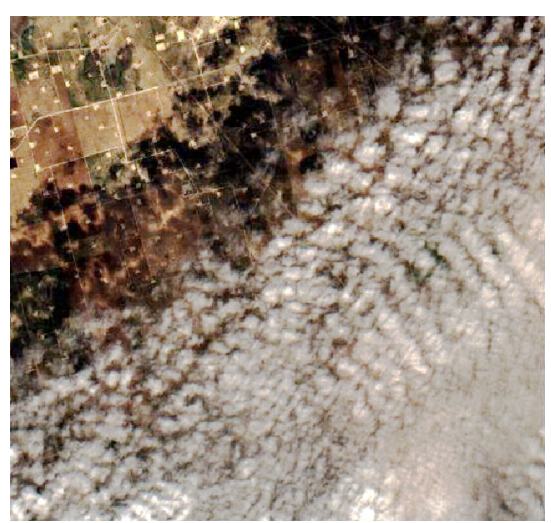

$b$

Fig. 1. Comparison of the dual-polarization C-band radar image from the Sentinel $1 A$ satellite (a) and optical multispectral visible band image from the Sentinel $2 A$ satellite (b) for the same territory and survey day

Sentinel 2A/B satellites to ensure all-weather monitoring of anthropogenic changes in areas of oil and gas production sites.

The input data and description of the image processing procedures. The territory of observations is areas of oil production in Texas, USA. As source data, C-band radar images from Sentinel-1A/B satellites and multispectral visible and infrared images from Sentinel-2A/B satellites are used. The C-band synthetic-aperture radar instrument provides a collection of data in all weather, day or night. This instrument has a spatial resolution of down to $5 \mathrm{~m}$ and a swath of up to $400 \mathrm{~km}$. The constellation is on a sun synchronous, near-polar $\left(98.18^{\circ}\right)$ orbit. The orbit has a 12-day repeat cycle and completes 175 orbits per cycle [10]. Sentinel-2 acquires optical imagery at high spatial resolution (10 to $60 \mathrm{~m}$ ). The mission is a constellation with two twin satellites (Sentinel-2A and Sentinel-2B).

Methodology. The proposed technology is implemented in the form of a software package consisting of two software modules:

- a module for processing C-band radar data obtained from Sentinel-1A/B satellites;

- a module for processing multispectral data of visible and near-IR bands obtained from Sentinel-2A/B satellites;

- a module for combine and visualization of processing results of multispectral and radar data.

Procedures for processing and analyzing radar images from Sentinel-1A/B satellites in order to simplify the user's work were divided into the preliminary operations and thematic processing operations.
Preliminary operations of the radar images processing are performed in full-automatic mode without manual operations. These operations include unpacking images of $\mathrm{HV}$ and VV polarizations and accompanying metadata, georeferencing by orbital data, radiometric and geometric correction, thermal and speckle noise filtration, transformation into a required cartographic projection.

Thematic processing operations of radar images from Sentinel-1A/B satellites are performed in a semi-automatic mode (Fig. 2). These operations include calculation of the ratio of $\mathrm{HV}$ and VV polarization channels, formation of the RGB composite and visualization, setting of binarization thresholds for new objects selection, morphological filtration and vectorization, formation of a thematic map and export of results into standard pixel and vector formats.

Block diagram of the automated recognition of new oil production sites in visible and infrared images from Sentinel2A/B satellites on the EOS web services in semi-automatic mode is shown in Fig. 3.

The normalized difference index (NDI) for a given pair of satellite images taken at different times and chosen spectral or polarization channels is computed as

$$
N D I_{i}=\left(B_{i}^{\text {new }}-B_{i}^{\text {old }}\right) /\left(B_{i}^{\text {new }}+B_{i}^{\text {old }}\right),
$$

where $i$ is the number of a spectral or polarization channel; new and old are indexes of earlier and later images.

Detection of new oil-extraction sites in multispectral images of the visible and NIR bands taken at different times from

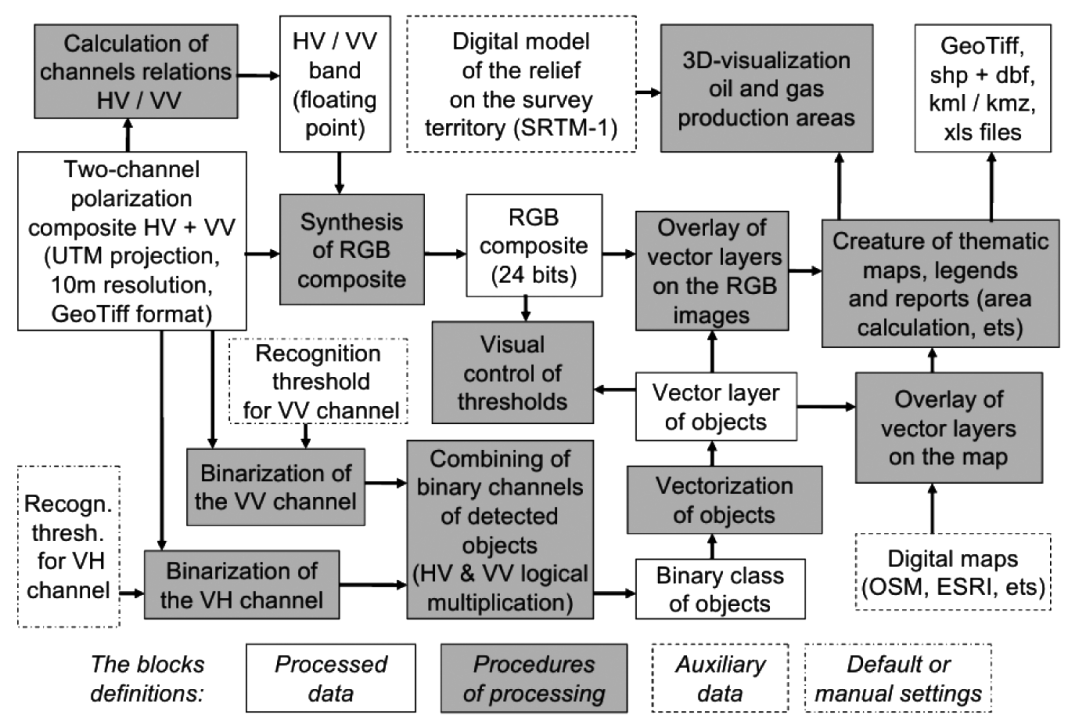

Fig. 2. Block diagram of the thematic processing of two-polarization SAR imagery (GRDH product) 


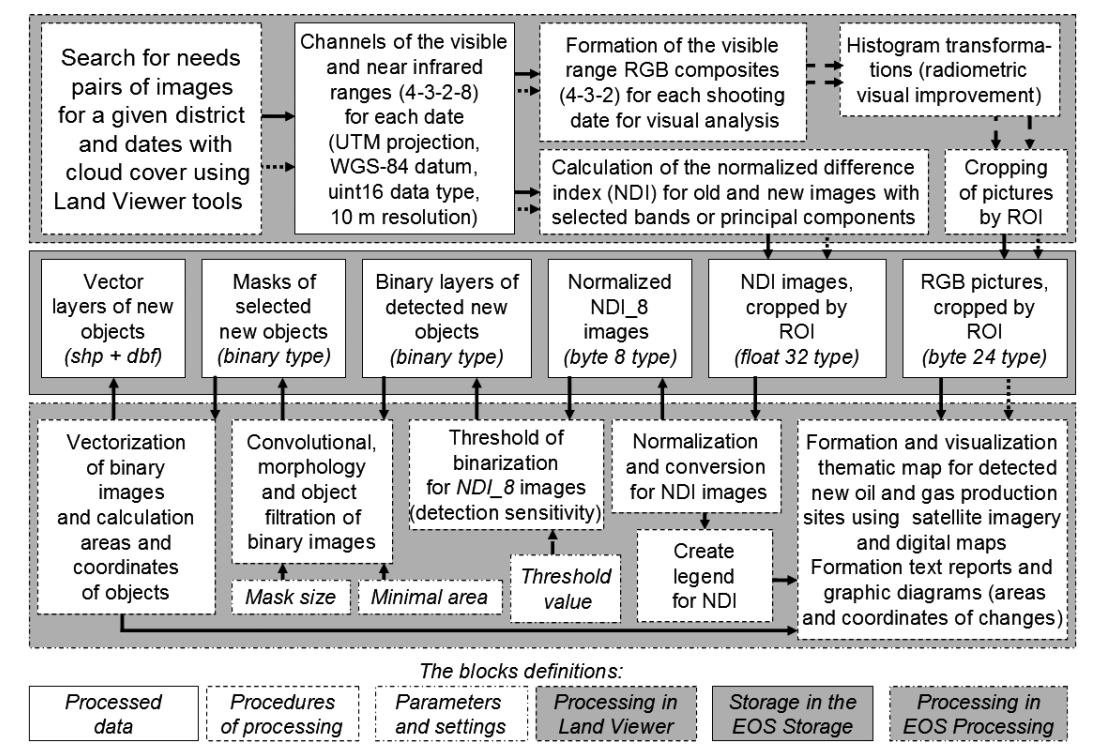

Fig. 3. Block diagram of the automated recognition of new oil production sites in visible and infrared images

satellites Sentinel-2A/B is done by solving these simultaneous inequalities

$$
\begin{aligned}
& \left(N D I_{\text {red }} \geq T_{\text {red }}\right) ; \\
& \left(N D I_{\text {red }} \geq T_{\text {green }}\right) ; \\
& \left(N D I_{\text {red }} \geq T_{\text {blue }}\right) ; \\
& \left(N D I_{\text {red }} \geq T_{\text {nir }}\right),
\end{aligned}
$$

where $T_{\text {red }}, T_{\text {green }}, T_{\text {blue }}, T_{\text {nir }}$ are the threshold values of detection of changes for respective spectral channels.

Detection of large metallic objects (drilling rigs, oil extraction rigs, oil storage facilities, tank trucks etc.) in bipolar $\mathrm{C}$-band radar images taken by Sentinel-1A/B satellites is done by solving the simultaneous inequalities

$$
\begin{aligned}
& \left(B_{V H} \geq T_{V H}\right) ; \\
& \left(B_{V V} \geq T_{V V}\right),
\end{aligned}
$$

where $T_{V H}, T_{V V}$ are the threshold values of detection of large metallic objects for respective polarization channels.

Requirements to the software and hardware. The volumes of remote sensing data files received from Sentinel satellites are usually quite large. For example, radar data of a scene taken from satellites Sentinel-1A/B in two polarizations can take several gigabytes. Therefore, for quick processing of such images in real time, it is desirable to use modern computers with multi-core processors of Intel class I-7 or higher and at least 64 GB of RAM. However, currently the most effective approach to processing and storing satellite imagery is to use specialized web services, for example, EOS engine (https://eos. com), that, compared to traditional software and hardware, have significant advantages, such as:

- work directly in the browser, which does not require additional software installed by the client;

- software and hardware independence, which allows using this web service on mobile devices;

- the results of image processing are stored on the server, which allows all customers to use the web service regardless of their location;

- high economic efficiency (no purchase of powerful graphic stations and expensive software is required);

- minimum requirements for the level of user training (there is no need to spend time on studying large and complex software packages).

Such web services allow users to select imagery sources, analytic operations, workflow and geospatial operations from various data and then instantly see the result of their query.
Choice of the accuracy assessment methods. The evaluation of the classification accuracy is accomplished by comparison of automatic classification with manual classification results [11]. A manual classification is prepared by an expert in the RGB images with the QGIS software using the same images and is considered as a model. The evaluation of the model accuracy has been accomplished by an expert method (5 experts with more than 10 years of practical experience in the processing of space images have been involved).

Model accuracy on average has been:

- 95-98\% for new oil production sites were recognized using RGB images from Sentinel-2A/B satellites;

- 93-95\% for big metal objects were recognized using SAR imagery from Sentinel-1A/B satellites.

For a quantitative evaluation of the errors of automatic recognition of new oil production sites as a result of processing of multispectral images in visible and near-IR bands from Sentinel-2A/B satellites, images with submeter spatial resolution from the Pleiades-1A satellite taken on the same day were used, in which the sites were manually recognized and then used as a standard.

The metrics that were used for the quantifying accuracy of the automatic classification are the following [11, 12]

$$
\begin{gathered}
\text { Accuracy }=\frac{T P+T N}{T P+T N+F P+F N} ; \\
\text { Detection Percentage }=100 \frac{T P}{T P+F N} ; \\
\text { Quality Percentage }=100 \frac{T P}{T P+F N+F P},
\end{gathered}
$$

where $T P$ is True Positive; $T N$ is True Negative; $F P$ is False Positive; $F N$ is False Negative [12].

The kappa $(\kappa)$ coefficient measures the agreement between classification and ground truth pixels. A kappa value of 1 represents perfect agreement while a value of 0 represents no agreement [12]

$$
\kappa=\frac{N \sum_{i=1}^{n} m_{i, i}-\sum_{i=1}^{n}\left(G_{i} C_{i, i}\right)}{N^{2}-\sum_{i=1}^{n}\left(G_{i} C_{i, i}\right)},
$$

where $i$ is the class number; $N$ is the total number of classified pixels that are being compared to ground truth; $m_{i, i}$ is the number of pixels belonging to the ground truth class $i$, that have also 
been classified with a class $i$ (i. e., values found along the diagonal of the confusion matrix); $C_{i}$ is the total number of classified pixels belonging to class $i$; $G_{i}$ is the total number of reference (i. e., standard, ground truth) pixels belonging to class $i$.

As an alternative method of quantitative evaluation of errors in automatic recognition of new oil extraction sites by processing Sentinel-2A/B images, it is possible to use data on calendar dates of development of extraction sites taken from corporate databases of the potential customers (when the access is available).

For a more accurate and reliable evaluation of errors in automatic detection of new oil extraction sites in images from Sentinel-2A/B satellites accomplished for the region of observations for the years 2016-2018, ground verification of the obtained results is necessary.

Results. Analysis of results of the automated processing of multispectral images of a given observation territory taken at different times from Sentinel-2A/B satellites in 2016-2018 has shown high effectiveness of the proposed method, in particular:

- sufficiently high (in comparison with visual recognition) sensitivity in detecting new oil extraction sites (Fig. 4);

- satisfactory (for a medium spatial resolution) accuracy of marking the boundaries of new oil extraction sites;

- good reproducibility of results of detection of new oil extraction sites in different test areas (at the same settings of the binarization thresholds);
- high stability of results of detection of new oil extraction sites in images taken on different dates at the same settings of the binarization thresholds (Fig 5);

- sufficiently good matching of new oil extraction site detection results in images from Sentinel-2A/B satellites and in superhigh spatial resolution images from the Pleiades-1A satellite (Fig. 6);

- a significant increase in speed of detection of new oil extraction sites in large territories in comparison with visual detection and manual vectorization (by about 100 times faster for a Sentinel-2A/B image).

Results of automated processing of two-polarization SAR imagery from Sentinel-1A/B satellites, raster masks and vector layers of recognized big metal objects (oil producing installations, oil storages, technical facilities, large vehicles for transportation of oil, etc.) with high value of the reflectance coefficient were obtained (red color objects in Fig. 7). Raster masks and vector layers of recognized new oil production sites (blue color objects in Fig. 7) are created as a result of automated processing of visible and infrared images from Sentinel-2A/B satellites.

The overall recognition accuracy, averaged for 20 test areas, was from 87 to $91 \%$ with the kappa coefficient ranging from 0.82 to 0.85 . For cloud-covered areas the big metal objects were recognized using SAR imagery from Sentinel-1A/B satellites only.

In the analysis of outcomes of automatic processing of multispectral images in visible and NIR bands from Sentinel-
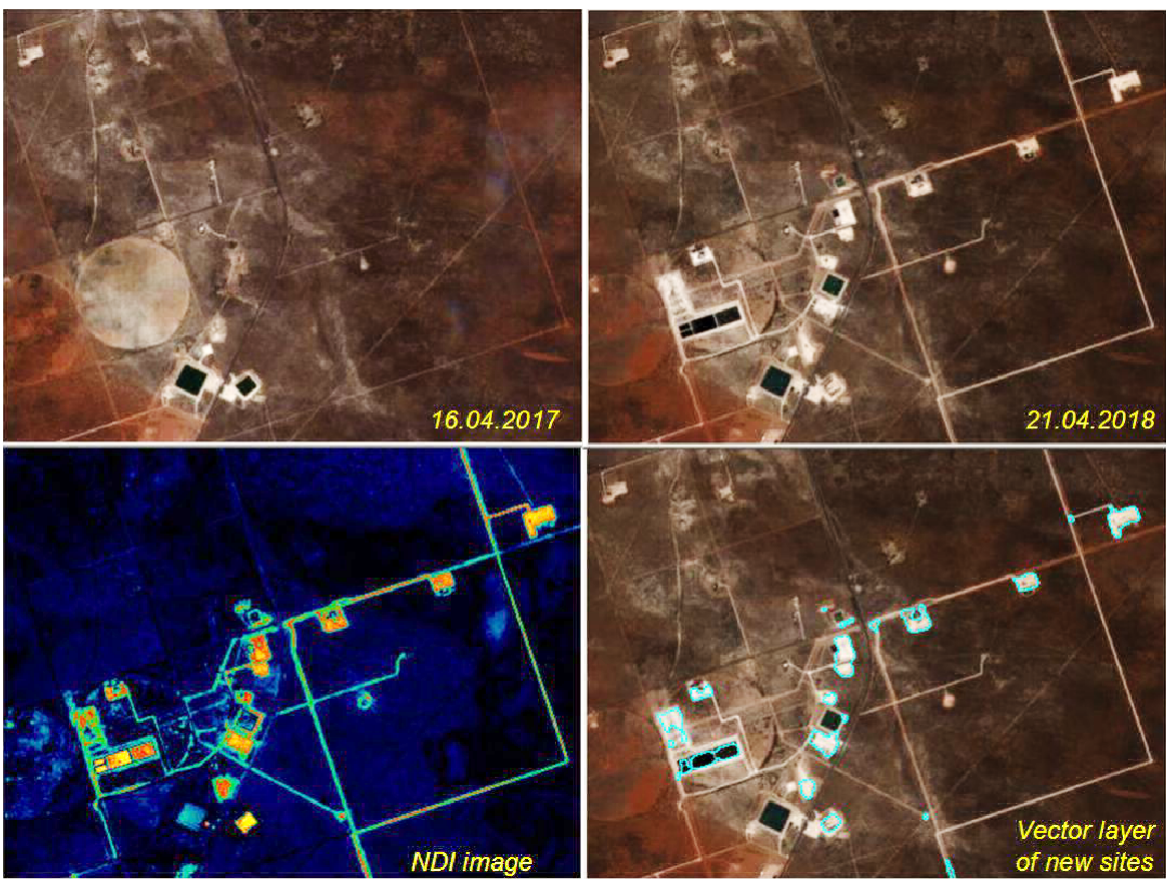

Fig. 4. Results of automated recognition of new oil production sites by two visible and infrared images from Sentinel-2A for 16.04.2017 and 21.04.2018

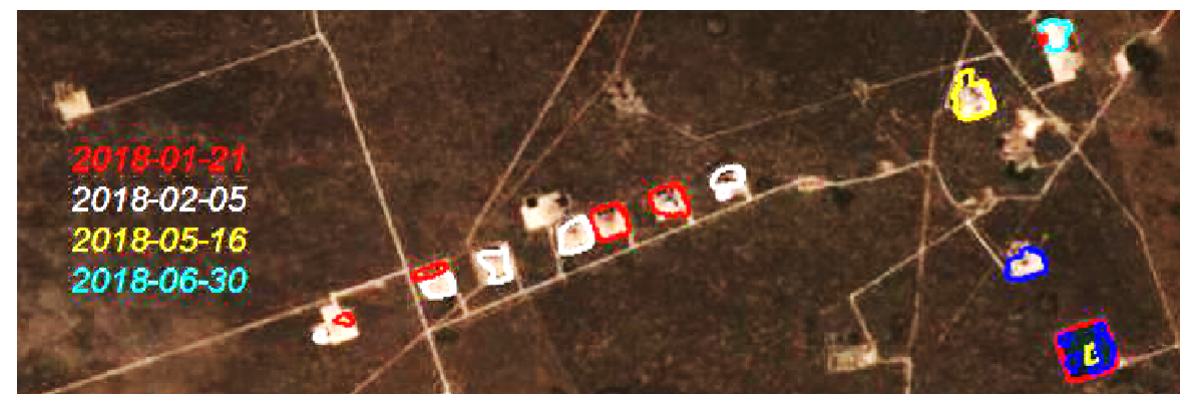

Fig. 5. Results Assessment of the dynamics of the construction of new oil production sites in a given observation area from January to June 2018 according to visible and infrared images from Sentinel-2A 


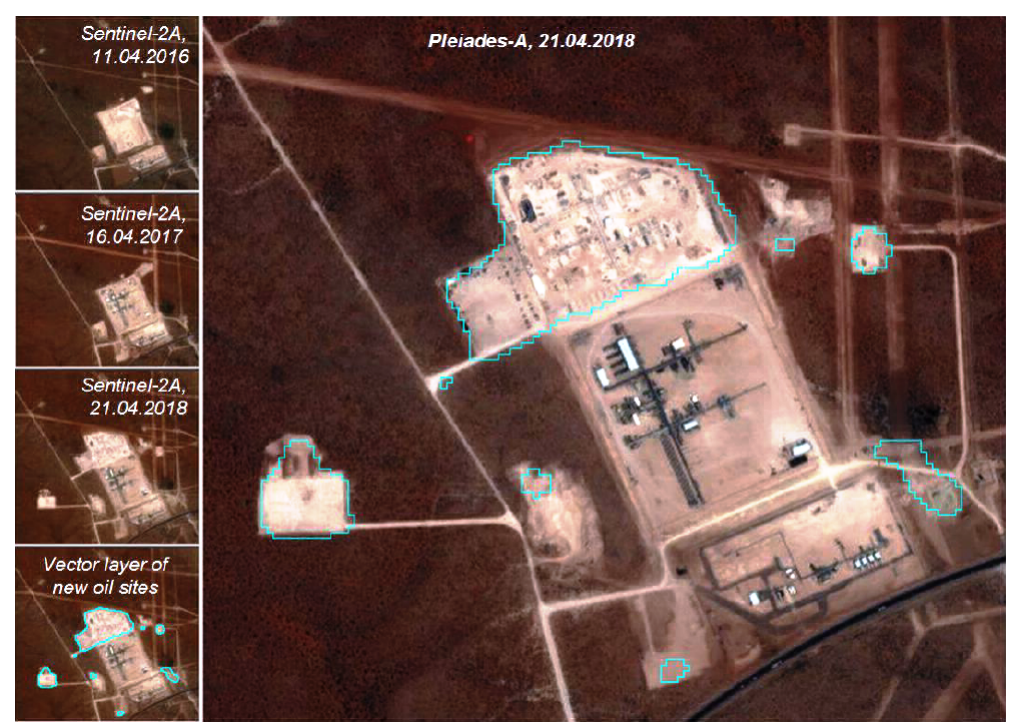

Fig. 6. Border accuracy assessment of new oil production sites in a given observation area from April 2016 to April 2018 according to visible and infrared images from Sentinel- $2 A$

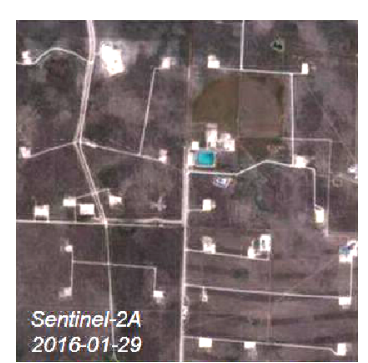

$a$

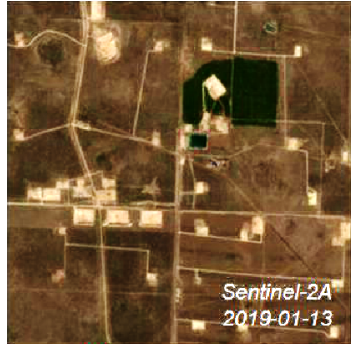

$b$

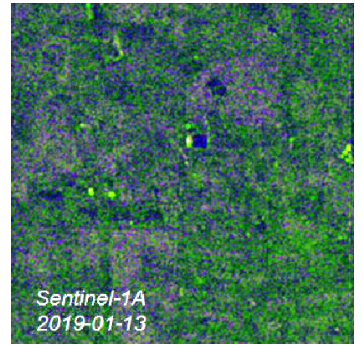

$c$

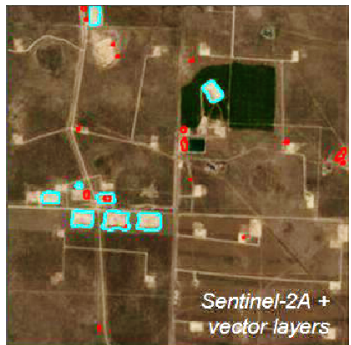

$d$

Fig. 7. Combine of automated processing results:

$a, b, c$-input images; $d$ - recognition results (Sentinel $1 A / B$ - red color of vector layer and Sentinel $2 A / B-b l u e$ color of vector layer)

2A/B satellites for 2016-2018 for the given monitoring regions, it appeared that, in some areas, insignificant (within $5-15 \%$ of the area of the recognized objects) false recognition of changes occurred (Fig. 8) due to the following factors:

- presence of insignificant cloudiness and shadows of the clouds;

- seasonal changes in vegetation and water bodies in the territory of imaging;

- different levels of illumination in two images taken at different time.

Besides, in the same analysis, on all test sites, insignificant (within 2-5\% of the area of the recognized objects) omission in recognition of changes was observed (Fig. 9) caused by the following factors:
- small geometric dimensions of such changes, within the range of a pixel (around 10 to $15 \mathrm{~m}$ );

- low contrast of the changed spots in comparison with the surrounding background;

- usage of the same settings in the image processing procedures for different sites and dates of imaging.

Currently, the proposed technology is being tested and tuned using multispectral images of various parts of the Earth obtained from active medium- and high-resolution satellites in order to determine optimal processing parameters for the main types of scanners taking into account the region and the imaging conditions.

Owing to the high degree of automation, simplicity and low requirements for computational resources, the developed

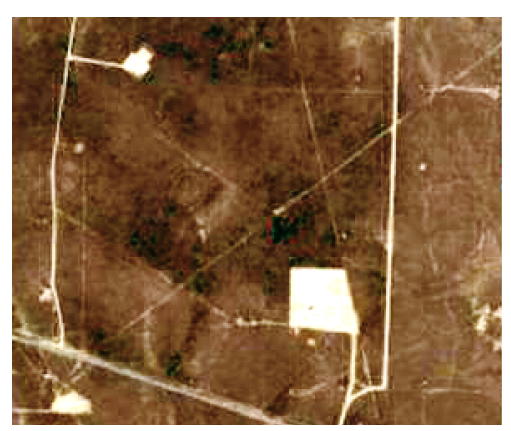

$a$

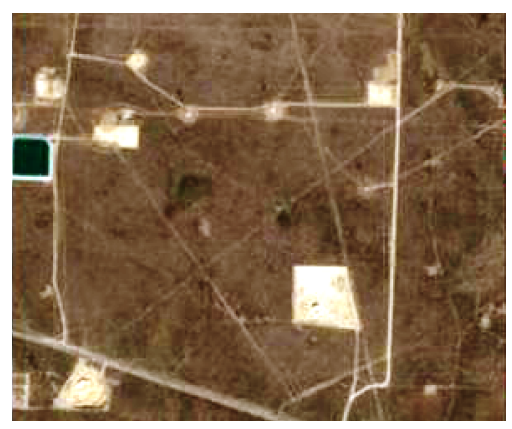

$b$

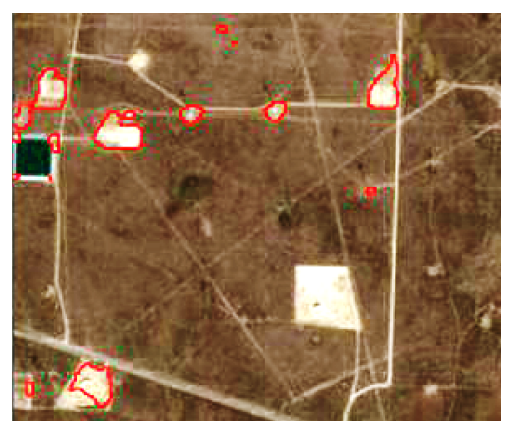

$c$

Fig. 8. An example of false recognition of changes by two visible and infrared images from Sentinel-2A: $a-16.04 .2017 ; b-21.04 .2018 ; c-$ recognition results 


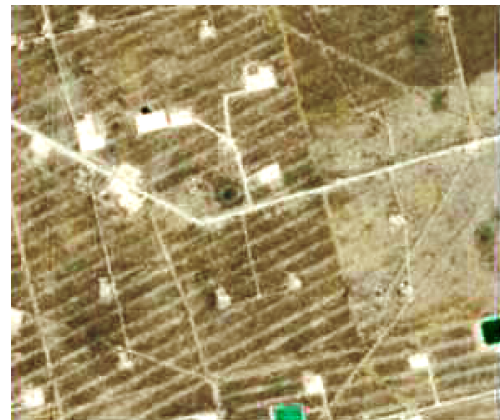

$a$

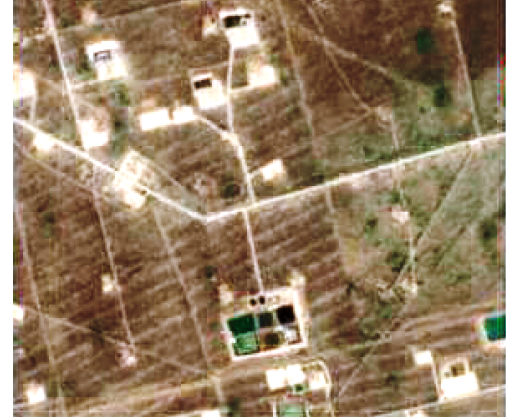

$b$

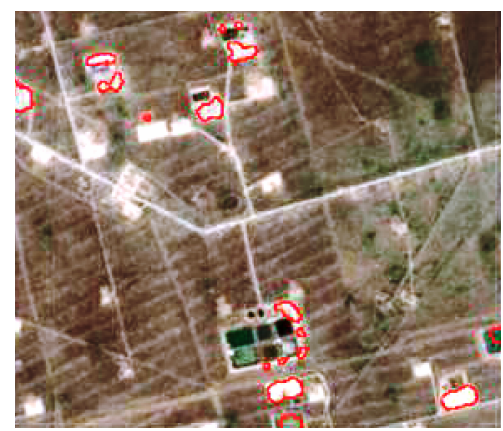

Fig. 9. An example of non-recognition of changes by two visible and infrared images from Sentinel-2A:

$a-16.04 .2017 ; b-21.04 .2018 ; c-$ recognition results

technology can be implemented in software as a geoinformation web service for all-weather up-to-the-date monitoring of oil-extraction regions. This web service can be used by:

- governmental supervisory bodies (supervision over development and production activities in oil-extraction areas);

- tax authorities and insurance companies (determination of the area of deposits, supervision over production activities and evaluation of the volumes of oil extraction);

- municipal services (monitoring and forecast of development of urban infrastructure in the territories of oil extraction);

- commercial organizations, trading companies, shipping companies (organization of supply and transportation in the oil extraction regions, analysis of activities of competitors);

- ecology services (evaluation of the technogenic pressure in the oil-extraction regions).

Conclusions. Remote sensing has a significant advantage over the traditional information technologies for oil and gas industry by reasons of high efficiency. The oil and gas industry is experiencing unprecedented challenges including new analysis techniques and complex drilling processes. The prospects for increasing the efficiency of using remote sensing to solve the problems of all-weather monitoring of oil and gas production areas are associated with the development of new technologies for processing aerospace information and with the fusion of optical and radar data. The proposed method enables automated detection of new oil extraction sites with the use of multispectral satellite images in visible and NIR bands taken at different times from Sentinel-2A/B satellites and also recognition of metal objects with the use of bipolarized radar images in the $\mathrm{C}$ band from Sentinel-1A/B. The results of experimental testing confirmed high effectiveness of the proposed technology.

Unlike the existing methods of detection of anthropogenic changes in the Earth's surface by satellite images (spectral indexes, clustering, controlled classification, transformation of the main components, convolutional neural networks and so on) requiring substantial computing power for the old and new images, the proposed technology uses immediate calculation of the normalized difference index of temporal changes NDI for a given pair of satellite images acquired at different times, which considerably reduces requirements to the computing power. Besides, the proposed technology ensures higher qualitative and quantitative indicators of the outcomes of satellite data processing, including:

- higher accuracy of delimitation of new objects of oil extraction sites;

- good reproducibility of results of detection of new oil extraction sites in different test areas (at the same settings of the binarization thresholds);

- high stability of results of detection of new oil extraction sites in images of different dates at the same settings of the binarization thresholds.

Further research will continue in the direction of increasing the monitoring accuracy using high spatial resolution aero- space data from satellites TerraSAR-X, Pleiades and WorldView-3. In our opinion, the data processing from drones is also a promising method for oil and gas pipelines monitoring. UAVs can detect methane leaks from oil and gas pipelines 1000 times more accurately than traditional instruments.

\section{References.}

1. Frassy, F., Maianti, P., Marchesi, A., Nodari, F.R., Dalla Via, G., De Paulis, R., ... \& Gianinetto, M. (2015). Satellite remote sensing for hydrocarbon exploration in new venture areas. 2015 IEEE International Geoscience and Remote Sensing Symposium (IGARSS). https://doi.org/10.1109/igarss.2015.7326417.

2. Lasica, R. (2015). A new age for oil and gas exploration remote sensing data and analytics are changing the industry. Earth Imaging Journal. Retrieved from http://eijournal.com/print/ articles/a-new-age-for-oil-and-gas-exploration-remote-sensing-data-and-analytics-are-chang-ing-the-industry.

3. Bondur, V. G., Vorobyev, V.E., \& Lukin, A. A. (2017). Satellite Monitoring of the Northern Territories Disturbed by Oil Production. Izvestiya, Atmospheric and Oceanic Physics, 53(9), 1007-1015. https://doi.org/10.1134/s0001433817090067.

4. Hnatushenko, V. V., Mozgovyi, D. K., Vasyliev, V.V., \& Kavats, O. O. (2017). Satellite monitoring of consequences of illegal extraction of amber in Ukraine. Naukovyi Visnyk Natsionalnoho Hirnychoho Universytetu, (2), 99-105.

5. Xing, Q., Meng, R., Lou, M., Bing, L., \& Liu, X. (2015). Remote Sensing of Ships and Offshore Oil Platforms and Mapping the Marine Oil Spill Risk Source in the Bohai Sea. Aquatic Procedia, (3), 127-132. https://doi.org/10.1016/j.aqpro.2015.02.236. 6. Miegebielle, V., Dubucq, D., Taillandier, C., \& Angeliaume, S. (2017). Use of Remote Sensing Radar Techniques for Oil and Gas O\&G Facilities Survey in Offshore Domain for Environment and Exploration: Oil Slicks Detection and Interpretation Seeps and Spill. In SPE Health, Safety, Security, Environment, \& Social Responsibility Conference - North America. https://doi.org/10.2118/184419-ms.

7. Franklin, M., Chau, K., Cushing, L.J., \& Johnston, J. (2019). Characterizing flaring from unconventional oil and gas operations in south Texas using satellite observations. Environmental Science \& Technology. https://doi.org/10.1021/acs. est.8b05355.

8. Unger, D., Hung, I-Kuai, Farrish, Kenneth, W., \& Dans, Darinda (2015). Quantifying Land Cover Change Due to Petroleum Exploration and Production in the Haynesville Shale Region Using Remote Sensing. Faculty Publications. Paper 43. https://doi.org/10.4018/ijagr.2015040101.

9. Liu, Y., Chao, S., Yang, Y., Zhou, M., Zhan, W., \& Cheng, W. (2016). Automatic extraction of offshore platforms using time-series Landsat-8 Operational Land Imager data. Remote Sens. Environ, 175, 73-91. https://doi.org/10.1016/j. rse.2015.12.047.

10. Solari, L., Del Soldato, M., Bianchini, S., Ciampalini, A., Ezquerro, P., Montalti, R., Raspini, F., \& Moretti, S. (2018). From ERS $1 / 2$ to Sentinel-1: Subsidence Monitoring in Italy 
in the Last Two Decades. Frontiers in Earth Science, (6), 149. https://doi.org/10.3389/feart.2018.00149.

11. Mozgovoy, D., Hnatushenko, V., \& Vasyliev, V. (2018). Accuracy evaluation of automated object recognition using multispectral aerial images and neural network. In Proc. SPIE 10806, Tenth International Conference on Digital Image Processing (ICDIP 2018). https://doi.org/10.1117/12.2502905.

12. Mozgovoy, D. K., Hnatushenko, V.V., \& Vasyliev, V.V. (2018). Automated recognition of vegetation and water bodies on the territory of megacities in satellite images of visible and IR bands. In ISPRS Annals of the Photogrammetry, Remote Sensing and Spatial Information Sciences, IV-3, 167-172. https://doi.org/10.5194/isprs-annals-IV-3-167-2018.

\section{Всепогодний моніторинг областей видобутку нафти та газу на основі супутникових даних} В. В. Гнатушенко ${ }^{1}$, Д. К. Мозговий ${ }^{2}$, Вік. В. Гнатушенко ${ }^{1}$, В. В. Спірінцев ${ }^{1}$, I. М. Удовик ${ }^{1}$

1 - Національний технічний університет „Дніпровська політехніка““, м. Дніпро, Україна, e-mail: vvgnat@ukr.net 2 - Дніпровський національний університет імені Олеся Гончара, м. Дніпро, Україна, e-mail: $\underline{\mathrm{m}-\mathrm{d}-\mathrm{k} @ \mathrm{i} . \mathrm{ua}}$

Мета. Розробка й тестування інформаційної технології автоматизованої обробки різночасових супутникових знімків середнього просторового розрізнення для всепогодного моніторингу районів видобутку нафти та газу.

Методика. Запропонована інформаційна технологія передбачає використання двох розроблених алгоритмів. Алгоритм автоматизованого розпізнавання нових нафтовидобувних майданчиків заснований на обчисленні нормалізованого різницевого індексу (NDI) часових змін для заданої пари різночасових супутникових знімків видимого та ближнього інфрачервоного діапазонів і вибраних спектральних каналів з подальшою багатопороговою бінаризацією. Алгоритм автоматизованого розпізнавання великих металевих об'єктів використовує двополяризаційні радарні дані C-діапазону із супутників Sentinel-1A/B.

Результати. Запропонована інформаційна технологія дозволила в автоматизованому режимі виявити нові нафтовидобувні майданчики та великі металеві об'єкти. Загальна точність розпізнавання, усереднена для 20 зон тестування, становила від 87 до $91 \%$ з коефіцієнтом каппа в діапазоні від 0,82 до 0,85 . Для областей, покритих хмарами, великі металеві об'єкти (нафтовидобувні установки, автозасоби для транспортування нафти й т.д.) були розпізнані з використанням тільки радарних даних із супутників Sentinel-1A/B.

Наукова новизна. На відміну від існуючих методів виявлення антропогенних змін земної поверхні за супутниковими знімками, запропонована інформаційна технологія використовує безпосереднє обчислення нормалізованого різницевого індексу часових змін NDI для заданої пари різночасових супутникових зображень, що істотно знижує вимоги до обчислювальних ресурсів, забезпечуючи при цьому більш високу точність виділення кордонів нових об'єктів нафтовидобувних майданчиків. Усепогодний моніторинг забезпечується використанням радарних даних.

Практична значимість. Завдяки високому ступеню автоматизації, розроблена інформаційна технологія може бути програмно реалізована у вигляді геоінформаційного веб-сервісу всепогодного оперативного моніторингу районів нафтовидобутку. Цілями такого веб-сервісу можуть бути визначення площі родовищ, контроль виробничої активності та оцінка обсягів нафтовидобутку; нагляд за будівельною й виробничою діяльністю та оцінка техногенного навантаження в районах нафтовидобутку.
Ключові слова: моніторинг нафтовидобутку, Sentinel$1 A / B$, Sentinel-2A/B, мультиспектральні знімки, обробка зображень, виявлення змін

\section{Всепогодный мониторинг областей добычи нефти и газа на основе спутниковых данных}

\author{
В. В. Гнатушенко ${ }^{1}$, Д. К. Мозговой ${ }^{2}$,
} Вик. В. Гнатушенко ${ }^{1}$, В. В. Спиринцев ${ }^{1}$, И. М. Удовик ${ }^{1}$

1 - Национальный технический университет „Днепровская политехника“, г. Днепр, Украина, e-mail: vvgnat@ ukr.net

2 - Днепровский национальный университет имени Олеся Гончара, г. Днепр, Украина, e-mail: m-d-k@i.ua

Цель. Разработка и тестирование информационной технологии автоматизированной обработки разновременных спутниковых снимков среднего пространственного разрешения для всепогодного мониторинга районов добычи нефти и газа.

Методика. Информационная технология предполагает использование двух разработанных алгоритмов. Алгоритм автоматизированного распознавания новых нефтедобывающих площадок основан на вычислении нормализованного разностного индекса (NDI) временных изменений для заданной пары разновременных снимков видимого и ближнего инфракрасного диапазонов и выбранных спектральных каналов с последующей многопороговой бинаризацией. Алгоритм автоматизированного распознавания крупных металлических объектов использует двухполяризационные радарные данные C-диапазона со спутников Sentinel-1A/B.

Результаты. Предложенная информационная технология позволила в автоматизированном режиме обнаружить новые нефтедобывающие площадки и крупные металлические объекты. Общая точность распознавания, усредненная для 20 зон тестирования, составила от 87 до $91 \%$ с коэффициентом каппа в диапазоне от 0,82 до 0,85 . Для областей, покрытых облаками, крупные металлические объекты (нефтедобывающие установки, автосредства для транспортировки нефти и т.д.) были распознаны с использованием только радарных данных со спутников Sentinel-1A/B.

Научная новизна. В отличие от существующих методов обнаружения антропогенных изменений земной поверхности по спутниковым снимкам, предложенная информационная технология использует непосредственное вычисление нормализованного разностного индекса временных изменений NDI для заданной пары разновременных спутниковых изображений, что существенно снижает требования к вычислительным ресурсам, обеспечивая при этом более высокую точность выделения границ новых объектов нефтедобывающих площадок. Всепогодность мониторинга обеспечивается использованием радарных данных.

Практическая значимость. Благодаря высокой степени автоматизации, разработанная информационная технология может быть программно реализована в виде геоинформационного веб-сервиса всепогодного оперативного мониторинга районов нефтедобычи. Целями такого веб-сервиса могут являться: определение площади месторождений; контроль производственной активности и оценка объемов нефтедобычи; надзор за строительной и производственной деятельностью и оценка техногенной нагрузки в районах нефтедобычи.

Ключевые слова: мониторинг нефтедобычи, Sentinel$1 A / B$, Sentinel-2A/B, мультиспектральные снимки, обработка изображений, обнаружение изменений

Recommended for publication by B. I. Moroz, Doctor of Technical Sciences. The manuscript was submitted 05.02.19. 